\title{
近隣空間の特性と領域化の関係
}

\section{集合住宅における近隣空間構成に関する研究 1}

$\begin{array}{lll}\text { 正会員野 } & \text { 口 瑠美子* } \\ \text { 正会員 谷 } & \text { 口 } & \text { 汎 }\end{array}$

\section{1. 序}

1-1 研究の目的・視点と構成

近年, 住宅地計画と近隣集団との整合性を段階論的に 追究した研究泣11６)，また，生活・環境維持管理単位とし で77の側面や地域性, 伝統性等の見直しを反映した, 近隣集団の基礎単位の研究 (後節, 表一11参照),さらに, 共有領域の研究社8)等, 住戸回り生活を重視する観点か ら，個と集合の関係を追究した研究等が注目される。す なわち, 個人の意識領域にまで踏み込み, 空間と生活と の対応をきめ細かに解明しようとする研究が見られる。

しかし，研究の進展にもかかわらす，近隣生活・集団・ 領域等の研究は，近隣空間計画につなげがたい面を依然 として持っている。しかも，低層から超高層に至る住宅 の多様化, 住棟や団地の大規模化, 高密度化, 近隣に対 し開放的でない住戸空間，住戸回りの半私的・半公的空 間の欠落化の傾向, 近隣空間・生活面共に伝統を継承し てない計画住宅地と既成市街地とが融合しにくい事等, 多くの問題をかかえる。そのため, 研究細分化の傾向も みられ，研究成果を系統的に十分計画に生かす段階に 至っていない。

そこで，領域等の研究を近隣空間計画に位置づける手 がかりを得るために，近隣空間における居住者の行動・ 意識上の節目となっていると考えられる点（分節点と略 す)ならびに中心となっていると考えられる空間・場(核 的場と略す) を抽出し，その特性を明らかにする事を本 論文の目的としている。また，その事を通して，低・中・ 高層住宅や居住階の差異等に基づく領域特性を明らかに したい。その方法は(1)団地生活上重要視されている“近 所” “連帯感や協力関係” (表一1, 項目 $1 \cdot 2$ 参照) なら びに “領域意識”等,つまり，行動・意識からみた範囲 を通じて, 間接的に分節点・核的場を把握し ( 2 章参照), (2)それ等を直接的設問方法による結果と照合して，分節 点・核的場の特徵をとらえる (3 章参照)。(3)さらに,

* 東海大学 助教授

** 東京工業大学 教授・工博 (昭和 60 年 4 月 10 日原稿受理)
分節点・核的場と領域化との関係，高層化に伴う領域の 性格の変化等を明らかにする (4 章参照)。

その際の領域の定義は「比較的広義によらえ, 居住者 の行動や意識からみて，いわゆる公的な空間亡は明らか に差異が認められる，住戸回りの半私的・半公的な空間 の意味である。したがって，領域内が性格によってさら に何段階かに分けられ，その一部がその性格から，例え ば共有領域致之認められる事等が考えられる」。ただし， 領域の性格の厳密な追究は別の機会に行いたい。また， 「領域化とは領域が形成される事，ある空間が領域内に 取り込まれる事」の意味である。

\section{1-2 調査概要}

この論文は主に多摩ニュータウン（＜多摩〉と略す） ならびに竹山団地（＜竹山>と略す）における調查結果 を基にまとめた。調查対象地域（表一 2 参照）は調查意 図に即応する事から選んだ。すなわち(1)同一団地内に複 数の住宅形式を含むため, 低・中・高層等の比較ができ る。(2)住棟形式の影響を避けるため, 類似の住棟形式に 統一できる。具体的には，低層は接地型と準接地型，中 層は階段室型, 高層は中層に合わせて, 階段室型にエレ ベーターが付設した形の板状ホール型を選んだ。(3)近隣 集合単位・形態が異なるため，それとの対応が明らかに なる。具体的には，〈多摩〉は複数の団地の中にあって， 各々が集会所を持つ，管理組合の単位で，その規模は低 層 $58 \cdot 130$ 戸，中層 380 戸，高層約 300 戸となっている。 一方の<竹山〉は立地条件や自治会活動, また, 池や商 店街を中央に配した形態等から，1団地のまとまりが強 いと推定される。住戸数約 2600 戸の団地である。<多

表一1 団地生活の善し悪しを左右する要素（住戸内を除く） (回答 3 つ以内)（）内は \%

\begin{tabular}{|c|c|c|c|c|c|c|}
\hline & \multicolumn{2}{|c|}{ 竹山団地 } & \multicolumn{3}{|c|}{ 8辟ニュータウン } & \\
\hline & 中是 & 高㭗 & 任有 & 中因 & 䤍展 & \\
\hline 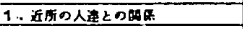 & $186(58.9)$ & $50(45,9)$ & $80(61.6)$ & 11769.2 & $91(58.3)$ & $504(58$ \\
\hline & $89(31.6)$ & $40(36.7)$ & $59(45.0$ & $64(37.9$ & $78(50.0)$ & \\
\hline 3. 用L & $21(7.4)$ & $5(4.6)$ & $15(11.5$ & $17(10.1)$ & & \\
\hline 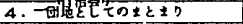 & $19(6.7)$ & 5( & $10(7.6)$ & $11(6.5)$ & $14(9,0)$ & \\
\hline 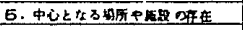 & $20(7.0)$ & $12(11: 0)$ & $11(8.4)$ & $14(8.3$ & $7(4.5)$ & \\
\hline 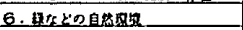 & $105(37.2)$ & $58(53.2)$ & $46(35.1)$ & $59(34.9)$ & $46(29.5)$ & $\sqrt{314(37}$ \\
\hline 7. & $34<12.1)$ & $20(18.3)$ & $12(9.2)$ & $12(.7 .1)$ & $17(10.9)$ & 111.2 \\
\hline 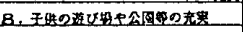 & $77(27.3)$ & $40(36.7)$ & $17(13.0)$ & $33(19.5$ & $24(15.4)$ & $1(225)$ \\
\hline 9. & $145(51.4)$ & $71(65.1)$ & $67(51.1)$ & $98(58,0)$ & $72(46.2)$ & 45 \\
\hline $10 .+0$ 地 & $7(2.5)$ & $1(0.9)$ & $5(3.8)$ & $2(1.2$ & $1(0.6)$ & $16(1)$ \\
\hline & $23(8.2)$ & $2(1.8)$ & $13(9.9)$ & $11(6.5)$ & $16(10.3)$ & $65<7$ \\
\hline & & & & & & \\
\hline
\end{tabular}


表一2 調查概要

\begin{tabular}{|c|c|c|c|c|c|c|c|c|c|c|c|c|c|}
\hline & & 所在地 & 住 形式 & 洋学形腎 & 精F & 醇 & 何 & 苦 & 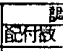 & 裔咅取 & 回取霍 & 品这期日 & 入居侍期 \\
\hline \multirow{4}{*}{$\begin{array}{l}\text { 多唐 } \\
\text { =ニータウン }\end{array}$} & 硬居 & 永山2-1 & 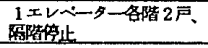 & 公団分㽬 & & $294 \bar{F}$ & 管理规合の些位 & 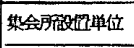 & 182 & 156 & $85.7 \%$ & \multirow{4}{*}{$\begin{array}{c}\frac{80}{56} \cdot 3.9 \\
5 \\
56.3 .18\end{array}$} & 5 3年 3 月 \\
\hline & 中圆 & 永 $3-1$ & 陆投室型 & " & 1 性 & $380 \bar{P}$ & " & " & 196 & 169 & 86.2 & & 47 年12月 \\
\hline & \multirow{2}{*}{ 低田 } & 水山 $\begin{array}{l}5-17 \\
5-20\end{array}$ & 低居メンネット型 & " & 1 钴 & $130 \bar{F}$ & $"$ & $"$ & 92 & 89 & 96.7 & & \begin{tabular}{|ll}
55 年 & 3月
\end{tabular} \\
\hline & & 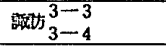 & タウンハウス & " & 11 钴 & $58 \bar{F}$ & $"$ & " & 47 & 42 & 89.3 & & 54年 3 月 \\
\hline \multirow{2}{*}{ 鸟山团地 } & 被居 & 椟市市竹山3-1 & 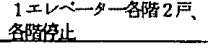 & 公杜分静 & 3模 & $180 \bar{P}$ & \multirow{2}{*}{\multicolumn{2}{|c|}{ 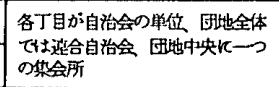 }} & 131 & 109 & 83.2 & \multirow{2}{*}{$\begin{array}{l}\text { 昭和 } \\
56.10 .29 \\
56.11 .2\end{array}$} & 4 6年度 \\
\hline & 中展 & 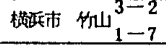 & 隆段室型，ボイント型 & " "，顼代 & 23 槽 & $504 \bar{P}$ & & & 348 & 282 & 81.0 & & $45 \cdot 6$ 年度 \\
\hline 一般住毛地 & & 解网活近江 & 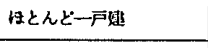 & \multicolumn{5}{|c|}{ 非周栖画住宅地 } & 107 & 103 & 96.3 & $\begin{array}{l}\text { 膯和 } \\
57.9 .16 \sim 18\end{array}$ & 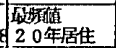 \\
\hline 吅原町卧地 & 被屈 & 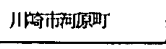 & 逆Y字型十H型，H型 & 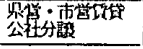 & 361 & $8 \widetilde{F}$ & 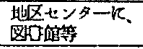 & & 961 & 710 & 73.9 & 咧和5年 12月 & 50 年底 \\
\hline
\end{tabular}

摩〉は公団，〈竹山〉は公社の団地であるが，ともに東 京郊外にあり，居住者の意識にほとんど差がないと考え た。住棟規模は低層 3〜12 戸，中層 10４0戸，高層 40 ～98戸であり, 高層の場合もあまり大きくない。本論 文における低・中・高層等の比較はあくまで，これ等の 条件を前提にしたものである。

調査項目は近所意識・範囲, 連帯活動・協力意識とそ の範囲, 住戸回りにおける行動・意識の拡がりならびに 中心となっているところ, 住戸回り空間に対する意識・ 要望, 近隣交流等である。調査方法は対象地域に居住す る主婦に対する留置式のアンケート方式とした。補足と しては，役員に対するインタビュ一調㚗，また，比較の ために, 近所意識・範囲等につき一般市街地（ほとんど 一戸建）調査を併せて夷施した。なお，調㚗にあたり， 既往の川崎河原町団地（複合片廊下型高層大規模住棟） 調䁞の結果を参考にするとともに, 一部それとの比較も
行った。

\section{2. 行動・意識等の範囲と空間・社会特性との間係}

2-1 住戸回りの行動・意識の㹡がり

歩行圏内を 9〜 10に分けて，行動・意識の拡がりを 5 ないし 9 項目泣9 にわたり調べた（図一1，2参照)。その 結果, 項目 A(「鍵をかけずにちよっと出ていけるとこ ろ」）では, 行為特性の影響として, 棟外の “ゴミ置場” を除くと，その範囲が，低層は“住棟前道路あるいは中 庭”, 中層は “住棟回り”, 高層は<竹山>の場合 “住棟 入口付近”, <多摩>の場合 “最寄りのエレベーターホー ル”程度までである。これは低・中・高層ともに, 後に 述べる「近所の範国」ともよく一致している。

この項目のほか， $\mathrm{E}$ (「見知らぬ人が歩いていれば気に なるところ」) ならびにF（「幼児を付きそいなしで遊ば せておけると思うところ」)についても, 高層の場合, “住 楎回り”“住棟入口付近” 等, 住棟周辺に関しては 6 階

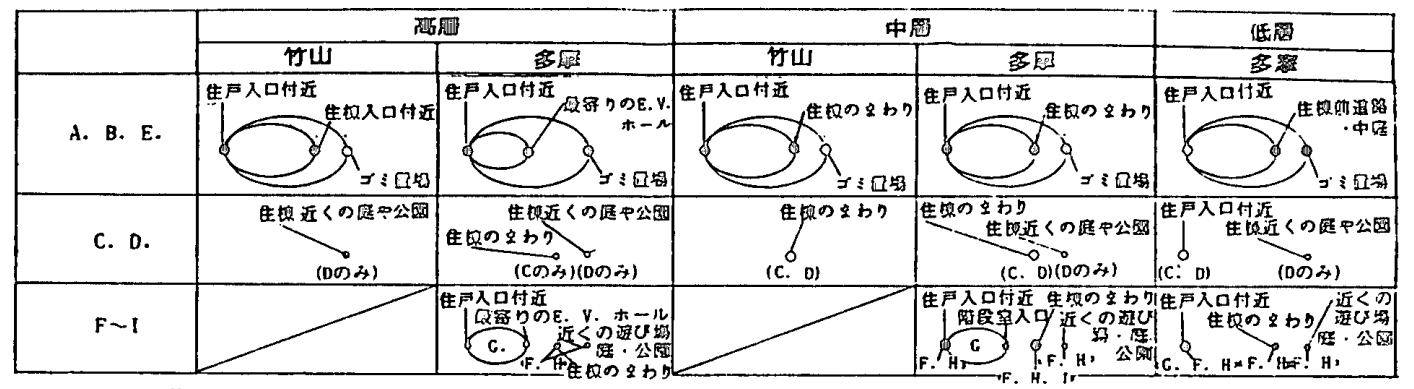

A.能をかけずにちょっと出ていけるところ

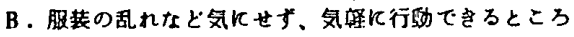

C.あなたが草机との手入れをするところ（月1回以

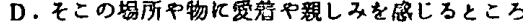

E. 見知らか人が步いていれは気になるとこる

（注）かかわりや意識の強さを丸印の大きさで示す。

図一1日常の行動・意識領域

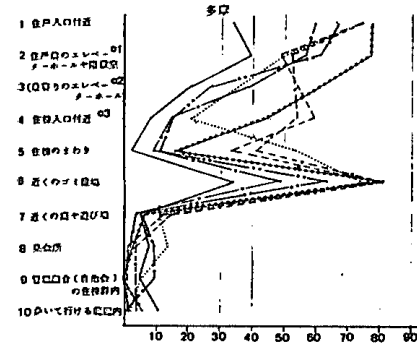

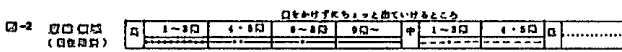

F，幼児を付きそいなしで遊ばせておけると思うところ

G.むなたか自発的に捅除をするところ（遇回以上）

H.人の目のあり、何とたく安心患のあるところ

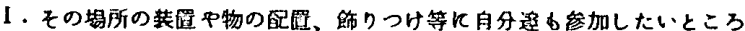

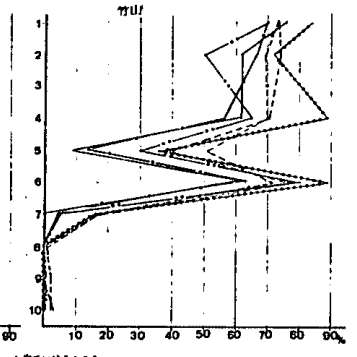

.

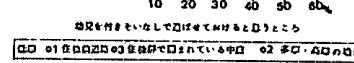
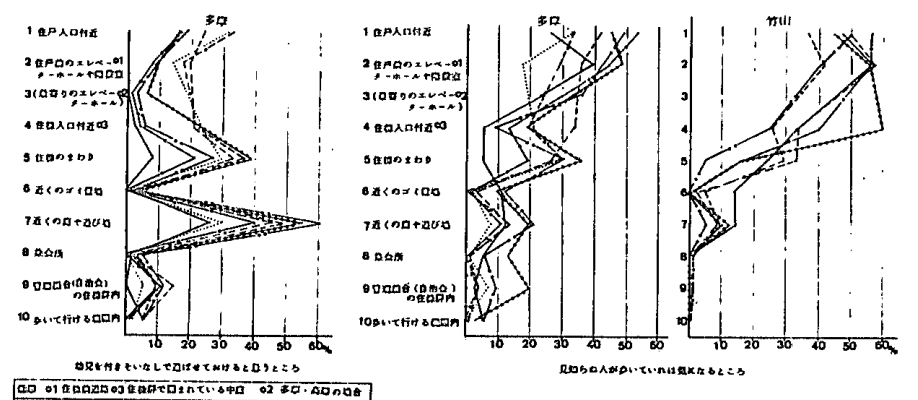

図一2 意識領域（居住階別） 
以上で，さらにく多摩〉では，“住戸入口付近”“住戸前 の階段室”等, 住戸のごく近くに関しては 9 階以上で, 下階との領域意識の差が認められた。なお, 高層複合片 廊下型の川崎河原町団地における同様の調查でも, “住 戸入口付近” “階の廊下” “団地内” 等の粗い領域段階に 分けられ, 住棟回り等の中間段階の領域意識の欠落傾向 がうかがわれた细10!。

また，「近隣生活とのつながり」についても（表一3 参照)，〈多摩〉の場合，“近くの庭，遊び場の様子”之
のつながりの要求が 6 階ないし 9 階以上では下がる。ま た，「気になる事柄」(表一 4 参照) でも“階段室等に人 目がなく不安”“近所の様子がかからない”の割合が 9 階以上で高くなる。すなわち，高所居住による地上階と のつながりやかかわりの希薄化，さらに，エレベーター アクセス等が領域拡大を規定していると考えられる。

2-2 連帯活動・協力範囲

次に, 連帯活動面等から，近隣の領域をとらえてみる。 まず，実際の活動単位はく多摩〉が主に管理組合（低層

表一3 住戸と近隣生活とのつながり要望 複数回答 単位 \% ※印は低層の場合

\begin{tabular}{|c|c|c|c|c|c|c|c|c|c|c|c|c|c|}
\hline & \multirow{2}{*}{ 多·低 } & \multicolumn{2}{|c|}{ 多・中 } & \multicolumn{2}{|c|}{ 竹・中 } & \multicolumn{4}{|c|}{ 多：高 } & \multicolumn{4}{|c|}{ 竹一高 } \\
\hline & & 1３階 & 4.5階 & 1 3 階 & $4 \cdot 5$ 階 & $1 \sim 3$ 階 & $4 \cdot 5$ 陌 & $6 \sim 8$ 䧑 & 9 階 & \begin{tabular}{|l|l|}
$\sim 3$ 階 \\
\end{tabular} & 4.5 際 & $6 \sim 8$ 階 & 9 階 \\
\hline 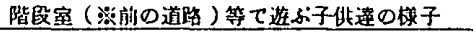 & 38.2 & 6.9 & 10.4 & 13.4 & 11.0 & 3.2 & 9.1 & 6.4 & 2.6 & 8.0 & 0 & 10.0 & 9.6 \\
\hline 階段室（独前の道路）䈉て行き来する人の栚子 & 6.9 & 5.7 & 4.5 & 7.6 & 2.4 & 6.5 & 9.1 & 6.4 & 13.2 & 12.0 & $\mathbf{0}$ & 6.7 & 9.6 \\
\hline 近所の人 & 0.7 & 3.4 & 3.0 & 4.5 & 6.1 & 9.7 & 0 & 0 & 2.6 & 0 & 0 & 3:3 & 4.8 \\
\hline 自分の & 26.7 & 27.6 & 26.9 & 13.4 & 19.5 & 22.9 & 30.3 & 29.8 & 39.5 & 12.0 & 0 & 13.3 & 19.0 \\
\hline 近くの庭や迨 & 26.0 & 60.9 & 64.2 & 33.8 & 35.4 & 58.1 & 60.6 & 48.9 & 34.2 & 32.0 & 25.0 & 46.7 & 52.3 \\
\hline 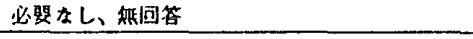 & 25.2 & 12.6 & 10.4 & 43.9 & 43.9 & 19.4 & 21.2 & 21.3 & 26.3 & 40.0 & 75.0 & 40.0 & 19.0 \\
\hline 合 斯 & 123.7 & 117.1 & 119.4 & 116.6 & 118.3 & 119.8 & 130.3 & 112.8 & 118.4 & 10.4 .0 & 100.0 & 120.0 & 114.3 \\
\hline （サンブル站） & $(131)$ & $(87)$ & $(67)$ & $(157)$ & $(82)$ & (31) & (33) & $(47)$ & $(38)$ & (25) & $(20)$ & $(30)$ & (21) \\
\hline
\end{tabular}

表一4 居住生活上, 気になる事柄（居住階別）

複数回答 単位 \%

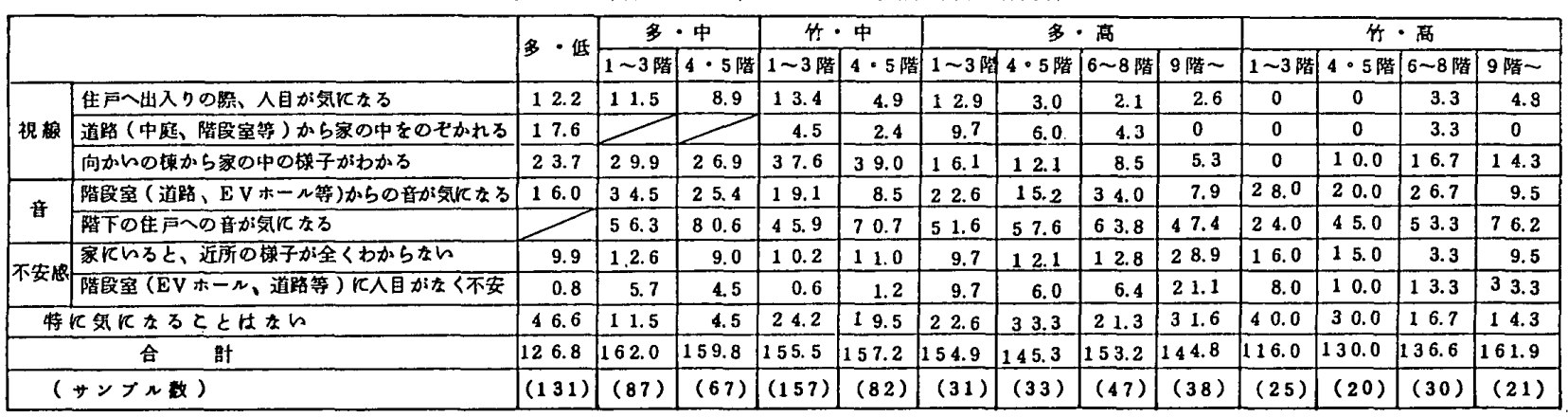

表一5 団地における居住者の連帯活動や協力関係

A. 居住者が共同でした事（全賸参加でない場合も含めて）

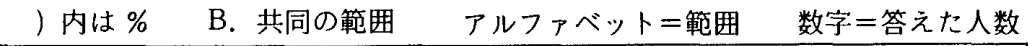

\begin{tabular}{|c|c|c|c|c|c|c|c|c|}
\hline & \multicolumn{2}{|c|}{ 角山团地 } & \multicolumn{3}{|c|}{ 多摩二=-タウン } & \multicolumn{3}{|c|}{ 多摩二ニータウン } \\
\hline & 中凨 & 要盛 & 低閶 & 中骨 & 高首 & 低用 & 中䦗 & 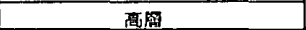 \\
\hline 1. $\frac{\pi 9}{2}$ & $118(41.8)$ & & $22(16.8$ & $62(36.7)$ & $37(23.7)$ & G 9, F 6, H 6, & $\mathrm{J} 29, \mathrm{H} 13, \mathrm{G} 11, \mathrm{~F} 11, \mathrm{~K} 7, \mathrm{I}$, & $\mathrm{F} 7$ \\
\hline 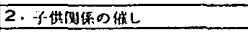 & $117(41.5)$ & $54(49.5)$ & $42(32.1$ & $79(46.7)$ & $72(46.2)$ & $F 29,58,66$, & F $34,321, \mathrm{~K} 10, \mathrm{G} 9, \mathrm{~A}$ 7, I 6 , & F 49 \\
\hline 3. 船拉 $\varepsilon y$ & $199(70.6)$ & $72(66.1)$ & $21(16.0$ & $62(36.7)$ & $38(24.4)$ & Q 13,47 & $\mathrm{H} 25, \mathrm{G} 16, \mathrm{~J} 15, \mathrm{I} 12$, & $\mathrm{H} 12, \mathrm{I} 9, \mathrm{G} 6$, \\
\hline 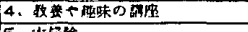 & $102(36.2)$ & $58(53.2)$ & $9(6.9$ & $41(24.3)$ & $59(37.8)$ & $(\mathrm{J} 3, \mathrm{G} 2, I 2)$ & G9.K8,J7, I $6, \mathrm{~A}_{5}$. & K 20, F 17, I 9, A 6, H 5, \\
\hline 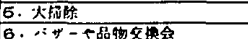 & $71(25.2)$ & $61(56.0)$ & $\frac{59(45.0}{12(0.2}$ & $\frac{80(47.3)}{46(27.2)}$ & $\frac{119(76.3)}{77(49.4)}$ & F 42.D9.G 6 , & F $64,08, A 5$. & $\mathrm{C} 60, \mathrm{~F} 38, \mathrm{D} 2 \mathrm{C}$ \\
\hline 7. 斯间的入 & $\frac{117(4.2)}{82(29.2)}$ & $\frac{2140.01}{52(47.7)}$ & $\frac{1+1.0}{34(26.0}$ & $49(29.0)$ & $61(39.1)$ & $\mathrm{K} 20, \mathrm{~F} Z$ & K $19 . F+1, A$ II I 5 & $\mathrm{~F} 18, \mathrm{~A} 14, \overline{\mathrm{K}} 13, G 6$ \\
\hline 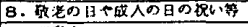 & $82(29.2)$ & $44(40,4)$ & & $14(8.3)$ & & & $(H 3, A 2)$ & $(\mathrm{K} 2)$ \\
\hline 9. 连而会 & $191(67.7)$ & $76(69.7)$ & $6(4.6)$ & $44(26.0)$ & $81(51.9)$ & $(6.3)$ & $F^{\prime} 31$. & F $59, \mathrm{G} 7$ \\
\hline 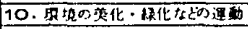 & $167(59.2)$ & $56(51.4)$ & $81(61.8$ & $119.70 .4)$ & $98(62.8)$ & F $68, D 7$ & F $99, D 6, G 5$ & $2,67, I 7$, \\
\hline \multirow{3}{*}{ 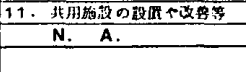 } & $26(9.2)$ & $17(15.6)$ & $9(6.9)$ & & $32(20.5)$ & \multirow{3}{*}{\multicolumn{3}{|c|}{ 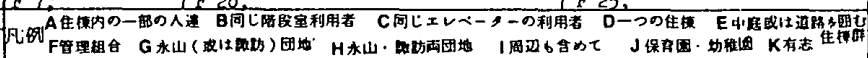 }} \\
\hline & $30(10.6)$ & $13(11.9)$ & $15(11.5)$ & & & & & \\
\hline & $282(100$ & $9(100)$ & $131(100)$ & $69(100$ & $156(100$ & & & \\
\hline
\end{tabular}

表一6 協力すべき面之協力範囲

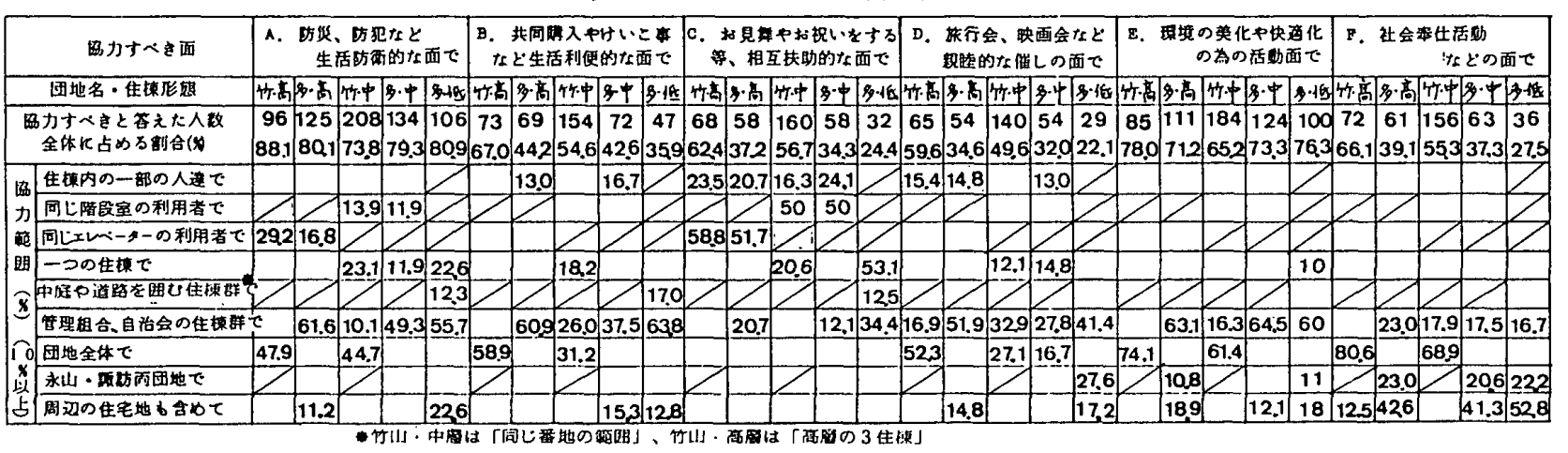




\section{表一7 近所の範册}

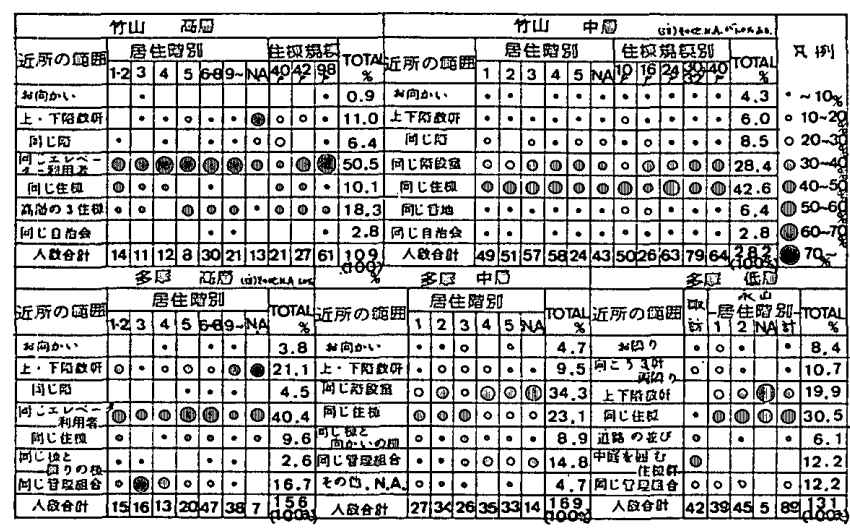

（注）竹山・中層ポイント棟（10戸）は 1 棟 1 階段室
表一8 近所の範囲の把握パターン（）内は住戸数

\begin{tabular}{|c|c|}
\hline 妡山・离屈 & 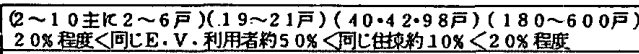 \\
\hline 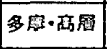 & 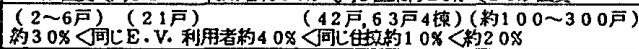 \\
\hline 劢山・中局 & 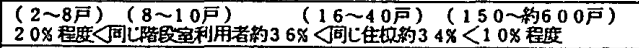 \\
\hline 多䀞·中井 & 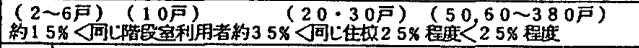 \\
\hline \multirow[t]{2}{*}{ 多回·低居 } & 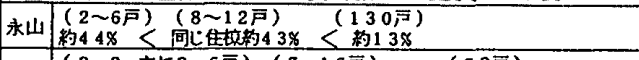 \\
\hline & 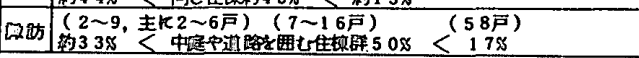 \\
\hline
\end{tabular}

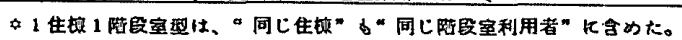

表一9 管理組合・連合自治会の基礎単位

。印は主な単位・組織

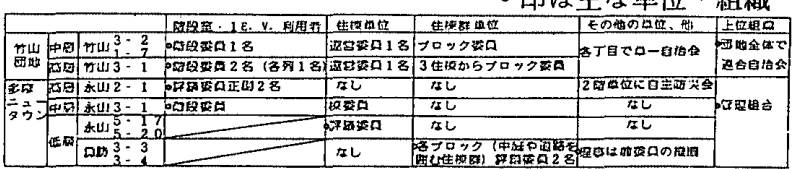

裴一10 近所の䉇囲とその理由

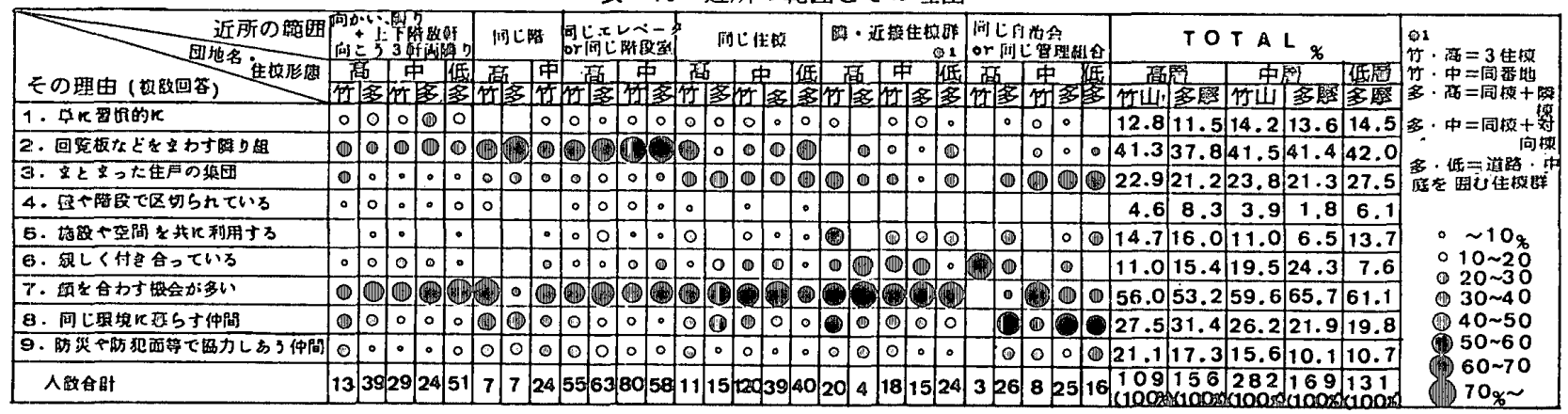

$58 \cdot 130$ 戸, 中層 380 戸, 高層 294 戸) (表一5参照), <竹 山〉は団地（約 2600 戸）(資料省略）である。その他 では，保育所・幼稚園が“祭”・“子供関係の催し”の単 位 (多摩・中層の場合), 各丁目 (583〜840戸) が“祭り” の単位で, 各丁目公園が“祭り”の場（竹山の場合）の 例等が注目される。

その活動内容は“環境美化・縁化運動” “子供関係の 催し”のほか, <竹山>の場合は“盆踊り”“運動会”, <多 摩〉は“大掃除”等である。

協力意識（表一6参照）は “生活防衛的面” “環境美 化面”が高く, また，〈多摩〉よりもく竹山>, さらに, 低・中・高層住宅の順に高くなる傾向は，活動種類の多 綮ならびに活動単位規模に比例する。協力範囲もく竹 山〉は主に団地，〈多摩〉は管理組合だが, “相互扶助面” では次節の「近所の範囲」とほぼ一致する。またく多摩〉 では個別の団地意識がほとんどなく，“社会奉仕活動面” 等では隣接団地を越え,ニュータウンの範囲まで拡がる。

\section{2-3 近所の範囲と近鲳意識との関係}

近所の範囲やその理由等を通じて, 近隣の領域を追究 すると（表一7〜10参照), 平均的な近所像は(1)アクセ スを共通にするグルーピング，(2)近隣組織の基礎単位， (3)一定幅で，しかも中・高層の方がより大きい住戸集合 規模等の特徵をもつ。(3)ついて詳述すれば,低層がく永 山>8 12 戸，〈諏訪>7〜16 戸，中層は（ほぼ同割合 の “階段室” “住楎” の加重平均値で ) <多摩 >18 戸 , <竹 山>21 戸，高層は19－21 戸である。ちなみに一般住宅

\section{表一11 基礎単位集合}

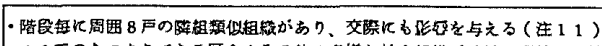

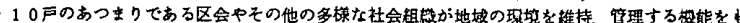
有している。(陆12)

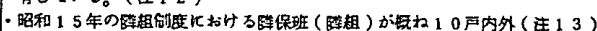

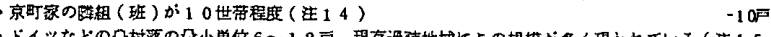

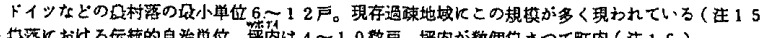

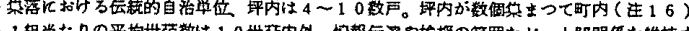

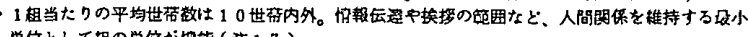

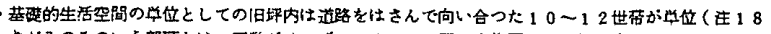

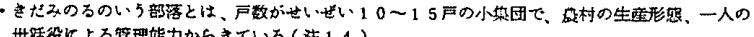

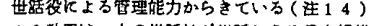

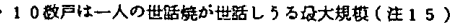

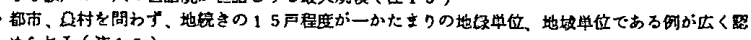
めら机(注15)

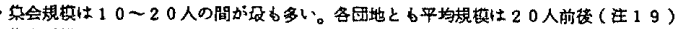

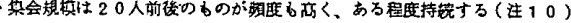

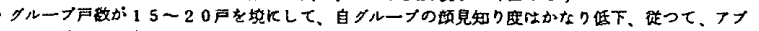

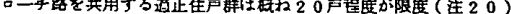

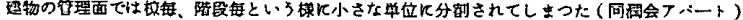

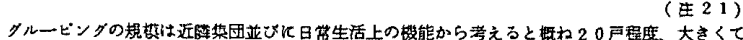

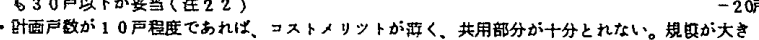

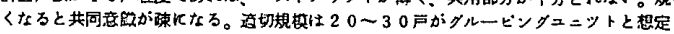

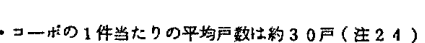

(在 23 ) (

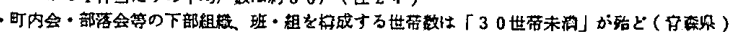

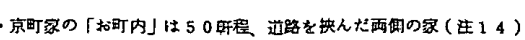

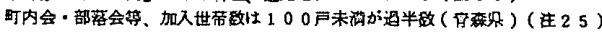

( 425 ) $-30=$ $-100 \mp-1$

地調㬈における平均は 14 戸だが，10 戸以内が $80 \%$ 以 上を占める等（資料省略），より小規模になっている。 なお，仲間・協力意識を近所の理由とする割合は低・ 中・高層の順に高くなり, 逆に, 低層の場合は“数軒” の割合が多い事から，向こう三軒両隣り意識が規定要因 となっているとみられる。

さらに，既往研究部11) 25)を基に考察しても（表一11 参照), 低層の場合に平均的に近所と考えられている規 模は, 既存の住宅地や村落における自治単位, 地縁単位, 
表一12 近所の人達のたまり場

A立与話しの場の場合—複数回答＼cjkstart単位％ ※印は低層の場合・印は“住棟群で团む中庭” $(29.0 \%)$ を含めた值

\begin{tabular}{|c|c|c|c|c|c|c|c|c|c|c|c|c|c|c|}
\hline & \multirow{2}{*}{ 多 - 低 } & \multicolumn{2}{|c|}{ 多・中 } & \multicolumn{2}{|c|}{ 竹 - 中 } & \multicolumn{4}{|c|}{ 多・高 } & \multicolumn{4}{|c|}{ 竹・高 } \\
\hline & & & 1 $\sim 3$ 階 & $4 \cdot 5$ 階 & $1 \sim 3$ 僣 & $4 \cdot 5$ 階 & $1 \sim 3$ 階 & $4 \cdot 5$ 階 & $6 \sim 8$ 慴 & 9 階一 & $1 \sim 3$ 慴 & 4.5階 & $6 \sim 8$ 階 & 9 階 \\
\hline \multicolumn{2}{|c|}{ 焦戸入口付近 } & 66.4 & 60.9 & 58.2 & 41.4 & 30.4 & 51.6 & 45.5 & 48.9 & 55.3 & 40.0 & 45.0 & 43.3 & 52.4 \\
\hline \multicolumn{2}{|c|}{ 住戸前の階段室 (策道路 ) 等 } & 27.5 & 11.5 & 7.7 & 15.9 & 30.4 & 29.0 & 12.1 & 19.1 & 23.7 & 4.0 & 20.0 & 16.7 & 38.1 \\
\hline \multicolumn{2}{|c|}{ 最寄りのEVホール } & & 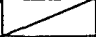 & 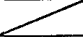 & 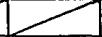 & 7 & 54.8 & 15.2 & 36.2 & 39.4 & 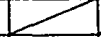 & 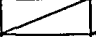 & 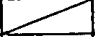 & $\angle$ \\
\hline \multicolumn{2}{|c|}{ 住㨂一階、入口付近 } & & 41.4 & 31.3 & 51.6 & 53.7 & 25.8 & 15.2 & 12.9 & 15.8 & 64.0 & 70.0 & 36.7 & 47.6 \\
\hline \multicolumn{2}{|c|}{ 近くの幼児の遊び場 } & 13.0 & 27.6 & 34.3 & 3.4 & 3.7 & 7 & 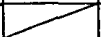 & 7 & 7 & 4.0 & 10.0 & 36.7 & 28.6 \\
\hline \multicolumn{2}{|c|}{ 近くの庭、公園等 } & .46 .6 & 49.4 & $\begin{array}{lll}3 & 1.3 \\
\end{array}$ & 45.2 & 40.2 & 58.1 & 51.5 & 42.6 & 34.2 & 52.0 & 20.0 & 43.3 & 23.8 \\
\hline \multirow{2}{*}{\multicolumn{2}{|c|}{$\begin{array}{l}\text { 策会所 } \\
\text { (サンブル数) }\end{array}$}} & 2.3 & 4.6 & 3.0 & & - & 9.6 & 15.2 & 14.9 & 15.8 & & & & \\
\hline & & $(131)$ & $(87)$ & $(67)$ & $(157)$ & $(82)$ & (31) & (33) & $(47)$ & $(38)$ & (25) & $(20)$ & $(30)$ & (21) \\
\hline & 多要 - 低置 & \multicolumn{3}{|c|}{ 多㻎 } & \multicolumn{6}{|c|}{ 多至・高屋 } & \multicolumn{2}{|c|}{ 何山・离展 } & \multicolumn{2}{|c|}{ 丁曰の大大さ } \\
\hline 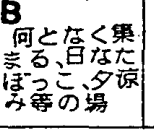 & 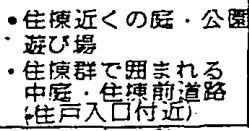 & \multicolumn{3}{|c|}{ 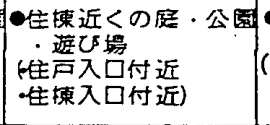 } & \multicolumn{2}{|c|}{ 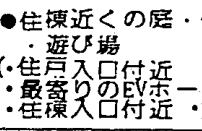 } & \multicolumn{4}{|c|}{ 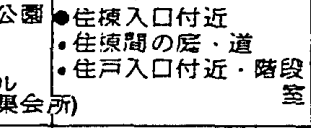 } & \multicolumn{2}{|c|}{ 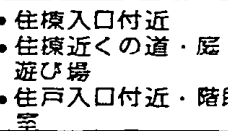 } & $\left\{\begin{array}{l}\text { 核的 } \\
\text { 合 }\end{array}\right.$ & $\begin{array}{l}\text { 乌造格の } \\
\text { 宗す }\end{array}$ \\
\hline
\end{tabular}

表一13 近所の範囲と交流人数（親しいつきあい）

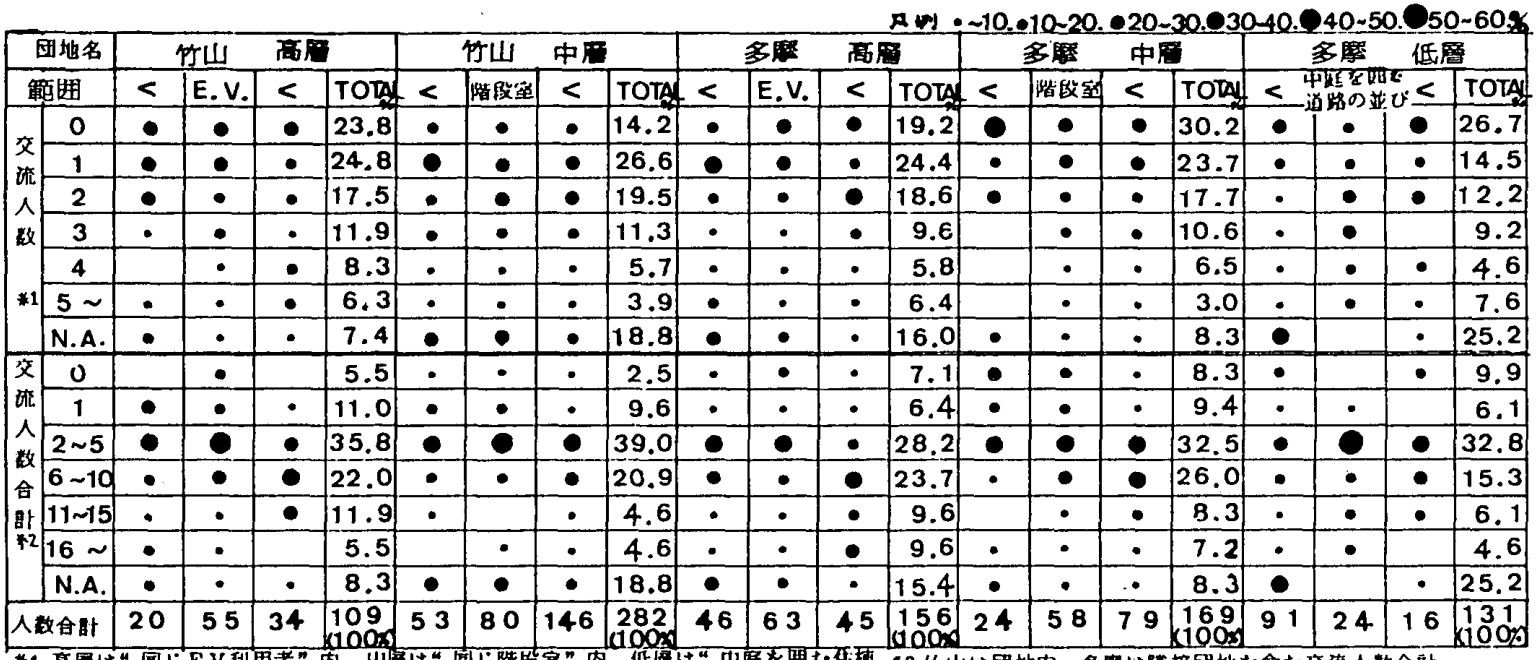

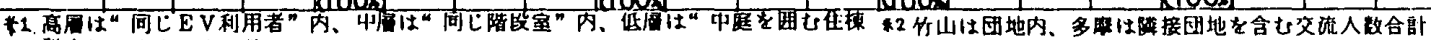
群内人枯方父硫人

表一14 催しなどの中心的場

アルファベット＝場所＼cjkstart数字＝答えた人数

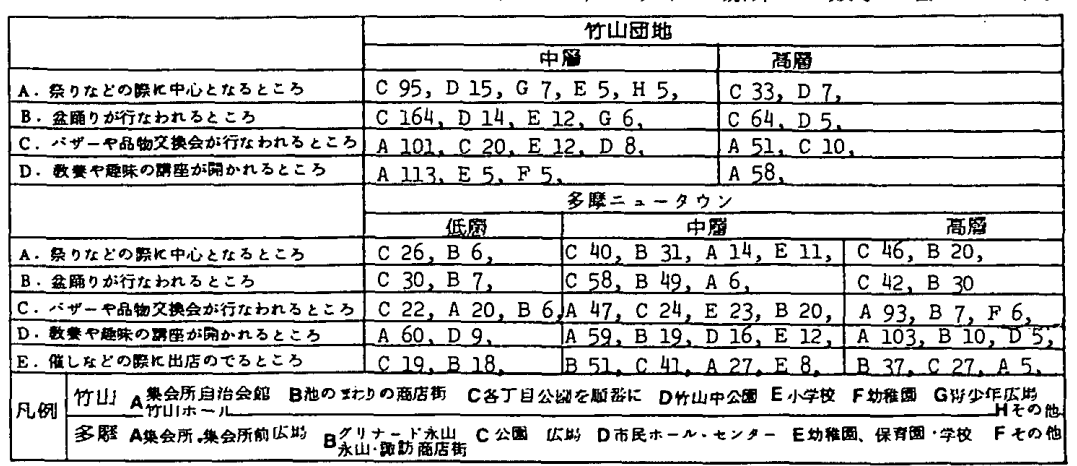

グルーピング化が近所の範囲に影響を 及ぼす。また，30代から居住する場 合や中・高層では下層階において，近 所を広範囲に考える傾向がみられた。 さらに，高層は中層と同程度の住棟規 模でも，1・2 階居住者を除き，住棟 範囲を近所と考える割合が低い事が注 目される。

\section{3. 行動・意識上の核的場 ・分節点 \\ 3-1 核的場}

引き続いて，居住者の行動・意識か
基礎的生活空間単位，人間関係維持の最小単位，隣組単 位,一人の世話役が世話しうる規模等に相当する。中層 高層の規模になると, 顔見知り, 共同意識, 集会規模, 近隣集団や日常生活機能上等，機能面を軸にした仲間集 団の意味合いが強まる事が理解される。

これ等の事は, 慣習性・伝統性等にも関連して，農村 よりも都市，既成市街地よりも計画住区，計画住区では 低・中・高層の順に，近隣の基礎単位規模拡大，意識変 質化傾向を類推させる。

なお，配置形態や場・施設，近隣組織等による住戸の
ら直接，近隣における核的場・分節点を探る。まず初め に，核的場の一つである近所の人達のたまり場は（表一 $12 \mathrm{~A} \cdot \mathrm{B}$ 参照)，(1)住戸・住棟入口付近，(2)近くの道・ 庭・遊び場・公園等で, (2)の“立ち話し”の場としての 機能は中・高層住宅では低層部で高い事，またく多摩・ 高層〉では集会所もいくぶんその機能を果たす事等を知 る。加えて，たまり場と交流との密接な関係，また，交 流圈拡大と交流人数の増加, さらに, 近所の範囲拡大の 傾向から (表一13参照), 核的場と近隣の領域との関連 が示唆されている。 
表一15団地の中心（居住階別）

単位 \% ※印は B 0 場合

\begin{tabular}{|c|c|c|c|c|c|c|c|c|c|c|c|c|}
\hline & \multicolumn{6}{|c|}{ 団地内の ${ }^{0}$ 中心的撒所。 } & \multicolumn{6}{|c|}{ 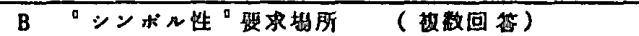 } \\
\hline & \multicolumn{2}{|c|}{ 竹・中 } & \multicolumn{4}{|c|}{ 竹・高 } & \multicolumn{2}{|c|}{ 竹 -中 } & \multicolumn{4}{|c|}{ 竹・高 } \\
\hline & $1 \sim 3$ 階 & $4 \cdot 5$ 階 & $1 \sim 3$ 管 & $4 \cdot 5$ 階 & 6〜8階 & 9 階 & 1 3 階 & $4 \cdot 5$ 階 & $1 \sim 3$ 階 & $4 \cdot 5$ 階 & $6 \sim 8$ 階 & 9 階一 \\
\hline 僠会所、浽集会所前 & 8. 9 & 9.8 & 0 & 5. 0 & 13.3 & 9.5 & 9.6 & 4.9 & 12.0 & 5.0 & 0 & 14.3 \\
\hline 住揀群て团し中涎 & 0 & 0 & 0 & 0 & 3.3 & 0 & 0 & 0 & 24.0 & 0 & 6.7 & 14.3 \\
\hline 公園 & 11.5 & 3.7 & $\mathbf{0}$ & 5.0 & 6.7 & 4.8 & 26.1 & 25.1 & 8.0 & 15.0 & 10.0 & 23.8 \\
\hline 他のま力り口栝 & 10.2 & 11.0 & 16.0 & 20.0 & 3.3 & 9.5 & 34.4 & 45.1 & 36.0 & 40.0 & 50.0 & 23.8 \\
\hline 池のまかりの商店良 & 59.9 & 70.7 & 76.0 & 70.0 & 56.7 & 71.4 & 0 & 0 & 0 & 0 & 0 & 0 \\
\hline 小学校、奻稚園、保青所 & 3.2 & 1.2 & 4.0 & 0 & 6.7 & 4.8 & 1.3 & 0 & 0 & 0 & 3.3 & 0 \\
\hline 千年他 & 2.5 & 2.4 & 4.0 & 0 & 6.7 & 0 & 4.4 & 10.1 & 0 & 0 & 0 & 0 \\
\hline なし、称回答 & 3. 8 & 1.2 & 0 & 0 & 3.3 & 0 & 37.6 & $\begin{array}{ll}3 & 1.7\end{array}$ & 40.0 & 50.0 & 36.7 & 42.9 \\
\hline (サンブル数) & $(157)$ & $(82)$ & $(25)$ & $(20)$ & $(30)$ & $(21)$ & $(157)$ & $(82)$ & $(25)$ & $(20)$ & $(30)$ & $(21)$ \\
\hline
\end{tabular}

表一16 管理組合の住棟群の中心（居住階別） 単位\%

（注）※印はBの場合

\begin{tabular}{|c|c|c|c|c|c|c|c|c|c|c|c|c|c|c|}
\hline & \multicolumn{7}{|c|}{ 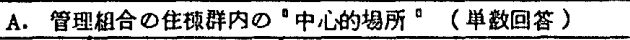 } & \multicolumn{4}{|c|}{ B. "シンボル性"要求䭪所 } & \multicolumn{3}{|c|}{ （被教回答） } \\
\hline & \multirow{2}{*}{ 多・低 } & \multicolumn{2}{|c|}{ 多・中 } & \multicolumn{4}{|c|}{ 多・高 } & \multirow{2}{*}{ 多・低 } & \multicolumn{2}{|c|}{ 多・中 } & \multicolumn{4}{|c|}{ 多・高 } \\
\hline & & $1 \sim 3$ 慴 & $4 \cdot 5$ 階 & $1 \sim 3$ 階 & $4 \cdot 5$ 䧄 & $6 \sim 8$ 陸 & 9 階 & & $1 \sim 3$ 隍 & $4 \cdot 5$ 墔 & $1 \sim 3$ 階 & 4 . 5階 & $6 \sim 8$ 階 & 9 階 \\
\hline 集会所、橴会所前 & 79.4 & 71.4 & 74.6 & 51.6 & 51.5 & 53.2 & 55.3 & 14.5 & 35.6 & 29.9 & 16.1 & 15.2 & 8.5 & 5.3 \\
\hline 住揤群内の庭 & 7.6 & 3.4 & 3.0 & 16.1 & 18.2 & 23.4 & 15.8 & 16.0 & 8.0 & 9.0 & 29.0 & 27.3 & 34.0 & 13.2 \\
\hline 幼児の遊び城 & 2.3 & 6.9 & 6.0 & 29.0 & 21.2 & 6.4 & 5.3 & 19.1 & 18.4 & 13.4 & 16.1 & 12.1 & 10.6 & 5. 3 \\
\hline 公圆 & 0 & 1.1 & 3.0 & 0 & 0 & 0 & 2.6 & 21.4 & 27.6 & 28.4 & 19.4 & 9.1 & 10.6 & 10.5 \\
\hline 住羡前 & 1.5 & 7 & 7 & 0 & 0 & 0 & 0 & 3.1 & 3.4 & 6.0 & 6.5 & 9.1 & 2.1 & 2.6 \\
\hline zof他 & 0.8 & 1.1 & 4.5 & 0. & 3.0 & 0 & 2.6 & 3.1 & 2.3 & 0 & 6.4 & 3.0 & 10.6 & 2.6 \\
\hline 現在あろ○て满足 & 7 & 7 & 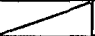 & 7 & 7 & 7 & 7 & 13.7 & 9.2 & 11.9 & 9.7 & 15.2 & 12.8 & 15.8 \\
\hline 万几、㸝回答 & 8.4 & 16.1 & 10.4 & 3.3 & 6.1 & 17.0 & 18.4 & 37.4 & 28.7 & 32.8 & 32.3 & 42.4 & 29.8 & 57.9 \\
\hline (サンプ几故 & (131) & $(87)$ & $(67)$ & (31) & (33) & $(47)$ & (38) & $(131)$ & $(87)$ & $(67)$ & (31) & (33) & $(17)$ & $(38)$ \\
\hline
\end{tabular}

明確に意識されている近榉集団の単位であるく多摩〉 の管理組合，〈竹山>の団地においては，“集会所”が 近㙹組織等の集会だけでなく,活動の中心的な場である。 また，“公園・広場”が祭り・盆踊り等の行事・催しの 中心的な場となっている。なお，“保育所・幼稚園”（多 摩 - 中層の場合), “小学校” (竹山の場合) も活動の場 としての可能性が示唆されている(表一14 参照)。

く多摩>の場合，管理組合の範囲に次ぐ上位の行事・ 催しの中心的な場としては, “駅前”ならびに“近隣セ ンター” 周辺の “商店街・公園・集会所等” が注目され, 自由意見でも，〈竹山〉は団地，〈多摩〉ではニュータ ウンにつき，コミュニティ・中心施設要求がみられた。

また，居住者が実際に「中心的な場所」竞26) と感じて
いるのは (表一15，16 参照)，〈多摩>の管理組合の範 井では主に, 活動の場と同じ“集会所”であり，〈高層〉 の場合は“住棟群内の庭・遊び場”も加わる。一方，<竹 山>の団地の範囲では, むしろ, 視覚的な面の中心となっ ている“池の回りの商店街”である。

「シンボル的なものが期待されている場所部27)」として は“公園・庭・遊び場”“池の回りや橋”“集会所前”等 が挙げられており，視覚的な面で中心的存在である事に 加え, 景観・環境面の重要性が示唆されている。なお, 上記のうち, “庭・遊び場”への期待がく多摩・高層〉 の 9 階以上では薄れる。

以上から, 近隣空間の段階別の核的場・空間の性格を 述べると，
表一17 仕切り・扉要求（住戸～住棟周辺）

複数回答（）内は答えた人数

\begin{tabular}{|c|c|}
\hline 多䁚・高圈 & 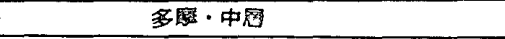 \\
\hline 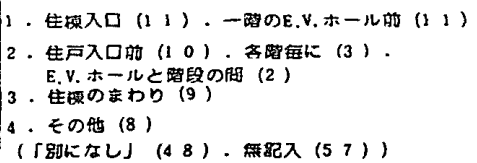 & 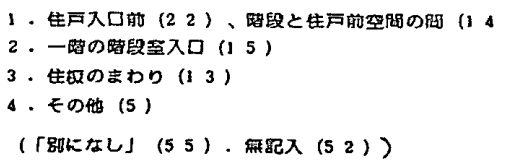 \\
\hline
\end{tabular}

表一19 住戸入口と住戸前の共用部分との間の関係（低層：前 の道路 (あるいは中庭))

\begin{tabular}{|c|c|c|c|c|c|c|}
\hline & \multicolumn{2}{|c|}{ 竹川団斯 } & \multicolumn{3}{|c|}{ 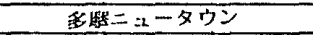 } & \multirow{2}{*}{ TOTAL } \\
\hline & 中网 & 酶解 & 低箄 & 中国 & 的居 & \\
\hline 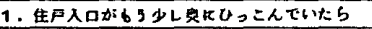 & $21(7.4)$ & $6(5.5)$ & $4(3.1)$ & $5(3.0)$ & $7(4.5)$ & $43(5.1)$ \\
\hline 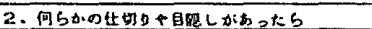 & $21(7.4)$ & $6(5.5)$ & $16(12.2)$ & $10(5.9)$ & $8(5.1)$ & $61(7.2)$ \\
\hline 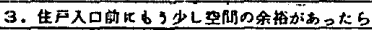 & $111(39.4)$ & $39(358)$ & $40(30.5)$ & $123(72.8$ & $71(45.5)$ & $384(45.3)$ \\
\hline 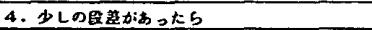 & $6(2.1)$ & $2(1.8)$ & $5 \hat{3.8}$ & $2(1.2$ & $4(2.6)$ & $19(22)$ \\
\hline 5. 七の伷 & $\begin{array}{ll}1 & (0.4) \\
\end{array}$ & $2(1.8)$ & 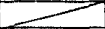 & $\longrightarrow$ & $\rightarrow$ & $3(0.4)$ \\
\hline 6. $40 \pm \pm \pi \mathrm{H}_{1}$ & $112(39.7)$ & $53(48.6)$ & $63(48,1)$ & $27(16.0)$ & $66(42.3$ & $321(37.9)$ \\
\hline 無眍入 & $10(3.5)$ & $2(1.8)$ & $4(3.1)$ & $3(1.8)$ & $3(.1 .9)$ & $22(2.6)$ \\
\hline TOTAL & $282(100)$ & $\begin{array}{l}110(100.9) \\
(109=100)\end{array}$ & $\begin{array}{l}132(1008 \\
131=100)\end{array}$ & $\begin{array}{l}170(1004) \\
(169=100)\end{array}$ & $\begin{array}{l}159(101.9) \\
156=100)\end{array}$ & $\begin{array}{l}853(1007) \\
(847=100)\end{array}$ \\
\hline
\end{tabular}

表一18 仕切り (へい，垣根，閒，木戸等) 要求

単位二答えた人数，複数回答

\begin{tabular}{|c|c|c|c|c|c|c|}
\hline \multicolumn{2}{|r|}{ 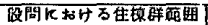 } & \multicolumn{3}{|c|}{ 5理祖合 } & \multirow{2}{*}{$\frac{\text { 闻德地 }}{\text { 地 }}$} & \multirow{2}{*}{$\frac{3 \text { 住玨 }}{406}$} \\
\hline & 到在対尔住区 & 多·㑑 & 多-中 & 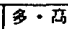 & & \\
\hline \multirow{6}{*}{$\begin{array}{l}\text { 校 } \\
\text { 周 } \\
\text { 昒 }\end{array}$} & 住顺の通ク & & & & 34 & 14 \\
\hline & 住顿前边䀩との間 & 6 & 15 & 7 & 28 & $\mathbf{8}$ \\
\hline & 特行者沟との間 & 9 & 13 & 4 & & \\
\hline & 国接住圾との間 & 7 & 7 & 2 & & \\
\hline & 对向住即々の間 & & 16 & & & \\
\hline & 要求者の制合(猈 & $(16.8)$ & 30.2 & $(8.3)$ & $(220)$ & $(20.2)$ \\
\hline \multirow{7}{*}{ 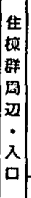 } & 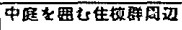 & 7 & & 7 & & \\
\hline & 当略住的的周召 & & & & 12 & $\mathbf{3}$ \\
\hline & 四接住填群との間 & 6 & 14 & 2 & & \\
\hline & 中逢の㟫り & 6 & & 2 & 7 & 2 \\
\hline & 住相群入口 & & 7 & & & 13 \\
\hline & 中医への入口 & 3 & & $\begin{array}{l}1 \\
5\end{array}$ & & \\
\hline & 要求者の的合(界) & $(198)$ & $(12 A)$ & $(10.9)$ & $(6.7)$ & $(16.5)$ \\
\hline \multirow{6}{*}{$\begin{array}{l}z \\
o \\
\text { te }\end{array}$} & 直道との問 & 10 & 14 & 9 & 23 & 10 \\
\hline & 旺草圾との闍 & 8 & 11 & 9 & 12 & 4 \\
\hline & その他 & 2 & & & 4 & 4 \\
\hline & 要求者の泟合( & $(15.3)$ & (148) & $(115)$ & $(13.8)$ & $(16.5)$ \\
\hline & 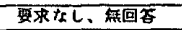 & 83 & 109 & 125 & 202 & 71 \\
\hline & サンブル婹 & 131 & 169 & 156 & 282 & 109 \\
\hline
\end{tabular}


表一20 一人で遊びに行く子供（2８才）に対する行動範囲限界の指示(「どこから先」「とこの外へ」行かないように)

子供 (2-8才) の主な遊び場

\begin{tabular}{|c|c|c|c|}
\hline & \multirow[b]{2}{*}{ （）内は答えた人数 } & （）内は答えた人数 \\
\hline & & & 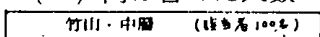 \\
\hline & $97: 11$. H田 & 讨 & \multirow{3}{*}{ 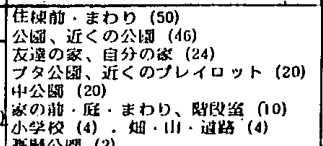 } \\
\hline $2 \cdot 3 \pi$ & 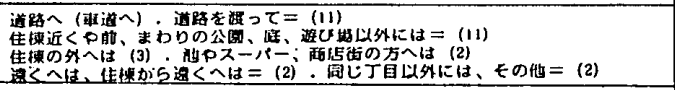 & 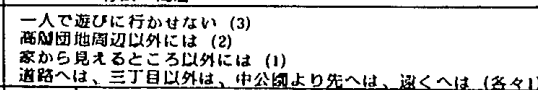 & \\
\hline \multirow[t]{2}{*}{$4 \cdot 5=$} & \multirow{2}{*}{ 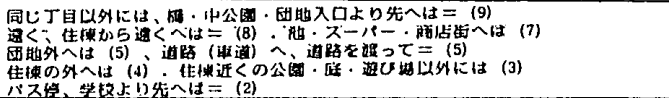 } & \multirow{2}{*}{ 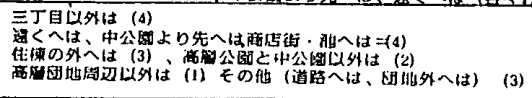 } & \\
\hline & & & 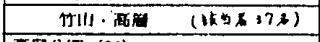 \\
\hline $6-8 \mathrm{~J}$ & 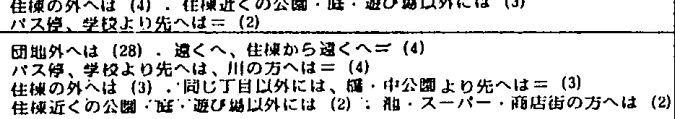 & 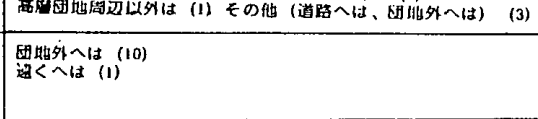 & 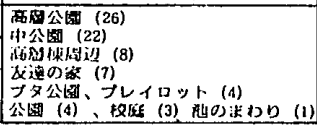 \\
\hline
\end{tabular}

(1)住戸回り・近所段階では住戸とのつながりが特に重 要であり，住戸との距離関係だけでなく，住戸内外の接 点空間の作り方にも深くかかわる。

(2)<中・高層>の管理組合の規模程度 300 380 戸(多 摩)では, 近隣組織・活動の場との関連が強く,したがっ て, 集会所と広場との一体化，さらに，中心的位置，環 境条件等により，核的性格が強まる可能性がある。

(3)団地規模 2600 戸（竹山）程度では，視覚的な面の 中心性, シンボル的なもの, 核的場のスケール感が重要 で，現状では商店街との関連か強い。

(4)団地を超えた二ュータウン的規模では，商業・コ ミュニティ施設を軸に，施設・場が線的あるいは面的に 連担し，生活ならびに心理・思惟的な拠点となる事等が 計画上重要な意味をもつものと思われる。現在は駅前や 近隣センターが核的場の役割を担っている。

すなわち，核的場を計画の観点から表現すれば，「居 住者の日常の行動線上にあり，行動・活動ならびに視覚 的な面等でのつながり・かかわりが緊密で，視覚的な面 での中心性，景観・環境面，スケール面やシンボル的な 面等からも，近隣空間の拠点としてイメージされやすい 場・空間である」。

\section{3-2 分節点}

近隣空間における分節点 (分節点の意味は 1-1 節参照) をへいや木戸等の何らかの “仕切り”の要求という面か らとらえてみると（表一17，18 参照)，中層では“住棟 周辺”が一つの分節点になっている。また，〈多摩・中 層>の例では“住戸入口前”にも分節化意識がみられる が，同空間の “拡大要求” の強さ（表一19参照）や溢 出物が最多である（資料省略）事等から，空間の領域化 と分節化意識との関連がうかがえる。さらに，高層の場 合は “住棟入口付近”, 低・高層の場合は “グルーピン グ化された住棟群”の“回り”ならびに“入口”にいく ぶん, 分節化意識がみられる。

子供（2－8才）の行動範囲之の関連からは（表一20 参照), <竹山・中層>の場合(1)住棟内, (2)住棟前 - 回り, (3)近くの公園・遊び場, (4)車道の手前, (5)橋・池・スパー・商店街の手前, (6)同丁目内, (7)バス停・学校まで, (8)団地内，の段階に分類できる。同時に， $2 \cdot 3$ 才では 団地内車道， $4 \cdot 5$ 才では橋・池・商店街，6 8才では
団地の境界が分節点となっている。なお，〈竹山・高層＞ の例から，高層住宅では $2 \cdot 3$ 才時に住戸内・周辺に限 定される傾向が強く，また，領域意識同様，“住棟前・ 回り”段階の欠落等, 加跉に伴う領域拡大の困難さが認 められた。

以上の結果ならびに 2 章で述べた行動・意識の範囲か ら，分節点の性格を示すと，次のようになる。

(1)分節点は空間・行動上の境目や住戸・住棟のグルー ピング化，近隣組織単位等に規定される。

(2)住戸回りにおける分節点は領域化と密接に関係す る。

(3)さらに，「空間・形態・社会上等の境目之行動・意 識上の節目である分節点が重なったとき，領域が形成さ れる」と言うことができる。

\section{4. 近隣空間の特性と領域特性との関係}

4-1 近隣空間の段階と高層化に伴う領域性の変質 近隣空間の特性と領域特性との関係の追究として,こ こでまず，これまでの分析結果を総括して近隣空間の段 階をとらえると (図一1, 3 参照), <多摩>の場合(1)近所, (2)管理組合の範囲，(3)ニュータウンで，個別の団地段階 が久落し，(2)が強く意識されている。しかし，低層の場 合は中・高層に比し，(2)がやや弱く，高層の場合は(1)の 段階が中層に比べ弱いと言える。（竹山＞では(1)近所, (2)団地で，(2)の範囲意識が強い。中間段階としては“各 丁目”ならびに高層の場合における“3住棟”の範囲が 意識されている。

また，両団地ともに中層住宅の特に下層階にみられる “住棟” の範团を近所と考える傾向と “住棟周辺” の領 域意識との相互関係，逆に，高層住宅の特に 6 階以上の 居住者にみられるそれ等の意識の希薄傾向は, 距離なら びにアクセス方式の差異等に基づく，地上階との実際 的・意識的なつながりの影響を示唆していると思われ る。中層同志の比較では，例えば，近所を“住棟”の範 囲之考える割合と住棟規模之の間に相関(カイ 2 乘検定, クラメア連関係数）が認められ，その際，27戸前後が 分岐点になっている。

したがって，防災面祀28)，環境の維持管理面，家屋協 同体的な考え方泣29)等からも要請される住棟単位のまと まりのためには，中層では 30 戸程度を上限とする等， 
表一21 住戸入口付近の装置

\begin{tabular}{|c|c|c|c|c|c|c|c|c|c|c|c|}
\hline \multirow{2}{*}{\multicolumn{3}{|c|}{ 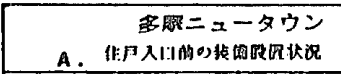 }} & \multirow{3}{*}{ 低解 } & \multirow{3}{*}{ 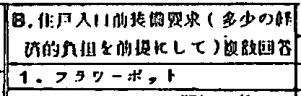 } & \multicolumn{2}{|c|}{ 㓛山阳山只 } & \multicolumn{3}{|c|}{ 急聚ニュータウン } & \multicolumn{2}{|l|}{ 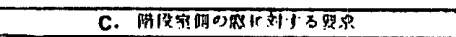 } \\
\hline & & & & & \multirow{2}{*}{$\frac{\text { 中阐 }}{10}$} & \multirow{2}{*}{\begin{tabular}{|l|} 
政 \\
15.69
\end{tabular}} & \multirow{2}{*}{\begin{tabular}{|c|} 
低䏸 \\
26.79 \\
\end{tabular}} & \multirow{2}{*}{\begin{tabular}{|l|}
198 \\
$35.5 \%$
\end{tabular}} & \multirow{2}{*}{\begin{tabular}{|l|} 
政風 \\
$30.7 \%$ \\
\end{tabular}} & \multirow{2}{*}{ 今照ニュータウン } & \multirow[b]{3}{*}{$3.2 \%$} \\
\hline & 办山 & EE⿰亻 & & & & & & & & & \\
\hline 1. $["] t]$ & $51.2 \%$ & $62.9 \%$ & $60.0 \%$ & 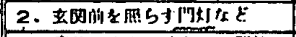 & 2.8 & 2.8 & 6.1 & 3.6 & 6.4 & 1. & \\
\hline 2. $P^{\prime \prime} \|$ HI & 22.6 & 0 & 5.0 & 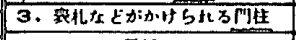 & 2.8 & 1.8 & 3.8 & 1.2 & 0 & 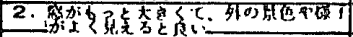 & 12.2 \\
\hline 3. "II $^{2}$ & 86.9 & $\mathbf{0}$ & 25.0 & 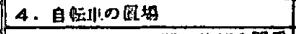 & 7.4 & 17.4 & & & & 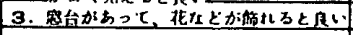 & 21.8 \\
\hline 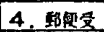 & 82.1 & 92.6 & 100.0 & 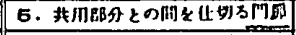 & 10.3 & 6.4 & 9.2 & 3.6 & 3.2 & 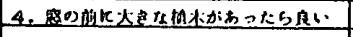 & 5.8 \\
\hline 5.t0他 & 1.2 & 7.4 & 0 & 6.・フとは剐の独した & 4.3 & 4.6 & 2.3 & 3.0 & 5.8 & 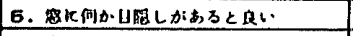 & 1.3 \\
\hline 然眍 入 & 0 & 0 & 0 & 7. †の船 & 2.2 & 2.8 & 11.5 & 3.0 & 3.8 & $0 . \uparrow \theta) 2 \tau R \omega$ & 51.3 \\
\hline & $84=$ & $27=$ & $20=$ & 8. 别 $6 \mathrm{C}_{\mathrm{K}} \mathrm{L}$ & 61.0 & 50.5 & 43.5 & 50.3 & 51.9 & 䀧貶入 & 5.1 \\
\hline & $100 \%$ & $100 \%$ & $100 \%$ & \begin{tabular}{|l|} 
無丽入 \\
\end{tabular} & 7.1 & 7.3 & 7.6 & 4.7 & 3.2 & & $156=$ \\
\hline & & & & TOTAL & 108.2 & 109.2 & 110.7 & 104.7 & 104.5 & & $100 \%$ \\
\hline
\end{tabular}

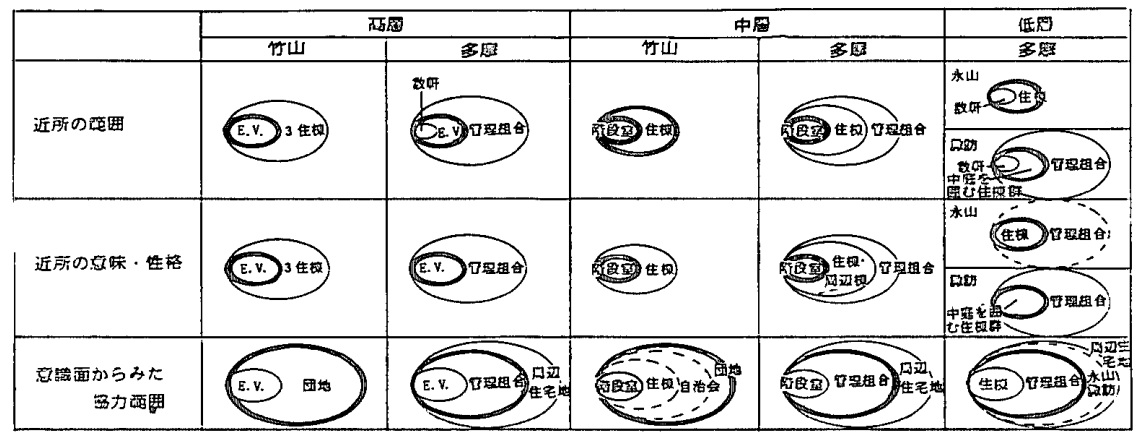

（注）領域確立の度合いの強さを太線, 細線, 点線で示す。 図一3 近隊意識領域の段階

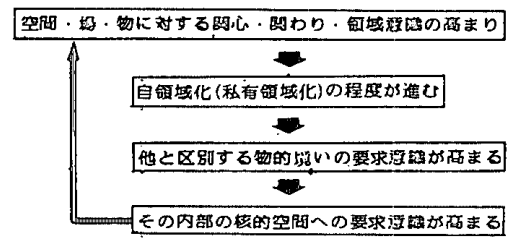

图-4

表一22 住棟（あるいは階段室）入口付近への要望 複数回答（）内は \%

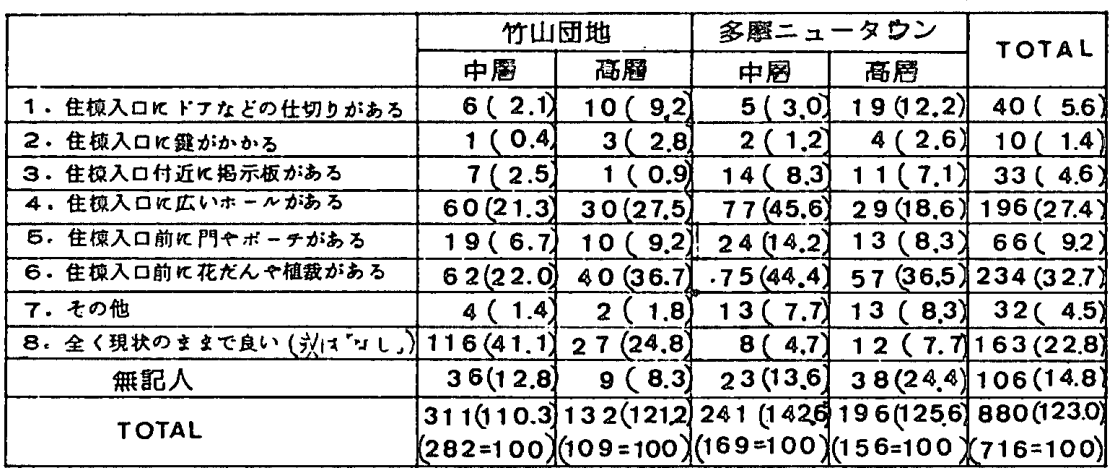

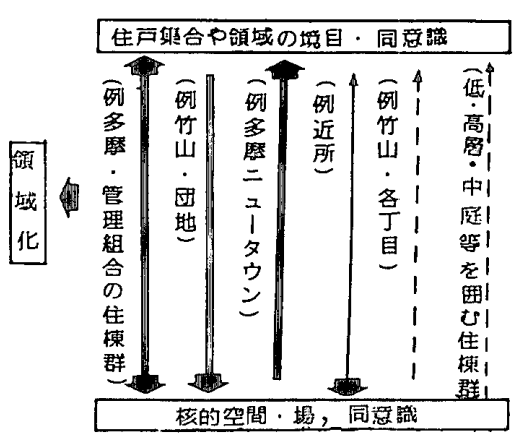

(矢印は作用の方向を示す)

図一5 領域化プロセス
規模の問題が重要である。高層の場合は結合の為の別の 仕掛けが必要と考えられる。その際，住戸入口付近にお ける“花等が飾れる空台”・“フラワーポット”要求（表 -21 A ・ B ・ C 参照)，住棟入口付近における“花壇・ 植栽”・“広いホール”要求（表一 22 参照）等に，核的 場の位圆ならびに機能面の一つのヒントが得られる。

加えて, “近くの庭・遊び場”等とのつながりも, 立 ち話し等, 実際の行動面では 6 階以上,つながり意識や 核的場に対する意識等, 意識面では 9 階以上で下階と差 を示す。また, 住戸入口付近や階段室, 住棟入口付近等, 住戸にごく近い空間に対する領域意識も 9 階以上では低 下し,“人目がなく不安”等の感じをいだく。換言すれば, 住戸近くさえ領域化されない傾向を示す。したがって， 領域化に向けて，例えば次節のごとく，分節化とその内 部における核的場の設置等, 計画面での配慮が必要と考 えられる。

一方, 近所の範囲等にみられた, 高層住宅における近 瀿の基礎単位規模の拡大化傾向は, 近隣組織単位ならび
に慣習的な近隣単位意識の希薄化の影響もあるが, 前述 の高層階における住戸近くの空間の非領域化, 逆に, 集 合単位の大規模化による連帯・協力活動の活発化の影 響, 換言すれば, 領域の段階性の欠落とそれに伴う居住 者の近䇟意識の変質化傾向を反映していると考えられ る。

\section{4-2 近隣空間の分節点・核的場と領域化との関係}

分節点・核的場と領域化との関係については，中層の “住棟”, 低・高層の“住棟群”の範囲についての意識 とその周辺との間の仕切りの要求との関係〔領域化 $\rightarrow$ 分節点要求了，また，中層の “住戸前” ““住棟回り”に おけるかかわり・領域意識の高揚による領域化と周辺と の仕切り要求に加えて, 内部における核的場の要求〔領 域化 $\rightarrow$ 分節点要求 $\rightarrow$ 核的場要求 $\rfloor$ 加，図一4に示す 循環過程が導き出せる。

さらに，近燃におけるたまり場とのかかわりやつなが り意識と近所の範囲の拡がりとの関係や近隣に対する視 線面のプライバシー意識の後退との関係から, 住戸回り 
の核的場による領域化・領域拡大〔核的場 $\rightarrow$ 領域化 · 領域拡大了が示唆されている。<多摩>におけるニュー タウン意識も, 駅前ならびに近隣センタ一周辺の強力な 核的場の存在と関係があると考えられる〔核的場 $\rightarrow$ 領 域化了。

〈竹山>の団地の範囲の場合は, 核的場よりも立地な らびに組織・活動上の境界が領域化に寄与していると思 われる[分節点 $\rightarrow$ 領域化]。<多摩>の管理組合の住棟 群の場合は, 住宅形式やその配置, さらに, 近隣組織・ 活動上の境界と集会所等の核的場との相互作用効果に よって, 上位領域との間に意識差が生じたと解釈される (分節点 $\longleftrightarrow$ 核的場 $\rightarrow$ 領域化] (図一 5 参照)。

以上，分節点と核的場との間ならびに両者と領域化と の間に関係がみられた。そこで, 分節点と核的場が領域 の限定や拡大, さらに, 領域の確定の程度等, 領域性の 操作・調節の手がかりになると考えられる。その際, 分 節点・核的場ともに, 物的面だけでなく, 行動・社会・ 意識面等を含め, 包括的にとらえるべきである。次論文 ではその意図から，閾泣31) (イキ，しきみ)・核概念とし てふえん化したい。

\section{5. まとめ}

以上を要約するよ次のようになる。

(1)近隣組織・活動単位, アクセスの共通性, 住戸集合 規模等が近隣意識とその範囲を規定すると思われる。

(2)近隣空間・組織等の節目と居住者の行動・意識の拡 がりには関連がみられる。

(3)近隣空間の段階は概略 2 ないし 3 に分けられ, 高層 は住棟の範囲や住棟周辺に対する意識等に中層と差がみ られる上，9階以上では住戸のごく近くさえ領域化され ない傾向がある。また，高層化ならびに集合規模の拡大 に伴う近隣意識の変質化傾向が認められた。

(4)中層では，特に住棟規模が 30 戸程度以下の場合に， 住棟が近隣集団の単位として，意識される傾向が強い。

(5)核的場・分節点の空間段階別の性格ならびに一般的 特徴,さらに，核的場・分節点と領域化との相互関係を 見い出す事ができた。

(6)分節点と核的場が領域の限定や拡大等, 領域性の操 作・調節の手がかりになると考えられる。

なお, 本研究につき森保洋之氏 (広島工業大学・助教 授）にご協力頂いた事を最後に付記し，謝意を表したい。

\section{注}

1) 栗原嘉一郎ほか：団地居住者における人間関係の展開之 コミュニティ意識, 団地居住者における生活時間・生活 圈, 団地居住者における人間関係の展開・生活時間 - 生 活圈・コミュニティ意識 (4編), 日本建築学会論文報告 集 $91 \cdot 92 \cdot 109 \cdot 124 \cdot 132 \cdot 139$ 号, 昭和 38 年 $10 \cdot 11$ 月· 40 年 10 月・ 41 年 6 月 - 42 年 $2 \cdot 9$ 月

2）野口美智子・水川尚彦：近所づきあいの範囲とヒエラル キ一に関する研究 $1 \cdot 2$, 日本建築学会大会学術講演梗概
集, 昭和 50 年 10 月

3）内井昭蔵建築設計事務所：高層住棟内の共用スペースに 関する研究, 日本住宅公団調查研究期報 No. 56 , 昭和 52 年

4）高橋 恒ほか：コミュニティ計画の基礎的研究 1３，日 本建築学会論文報告集 $246 \cdot 247 \cdot 306$ 号, 昭和 51 年 $8 \cdot$ 9 月・ 56 年 8 月

5）足立 孝ほか：地域融和の観点からみた公共公益施設の 立地ならびに整備基準に関する研究 $1 \cdot 2$, 日本住宅公団 調查研究期報 No. $45 \cdot 57$, 昭和 $49 \cdot 52$ 年

6）野口瑠美子：高層集合住宅における近隣関係研究に関す る建築計画的一考察, 東海大学教養学部紀要第 4 輯, 昭 和 48 年, 参照

7）野口瑠美子：集合住宅並びにその団地に関する研究及び 計画理念の動向, 東海大学教養学部紀要第 15 輯, 昭和 59 年, 参照

8）小林秀樹・鈴木成文：集合住宅における共有領域の形成 に関する研究 1一共有領域の構造, 日本建築学会論文報 告集 307 号, 昭和 56 年 9 月

9）<多摩>の場合は川崎河原町団地調查結果 (注 10 参照), 〈竹山>の場合はく多摩>の調查結果を参考にして, 調 查項目を設定した。

10）谷口汎邦・野口瑠美子ほか：住戸まわりに関する領域意 識と共用空間への機能要求について, 日本建築学会大会 学術講演梗概集, 昭和 52 年 10 月

11）足立 孝：集合住宅に対する居住者の心的緊張調查 1 , 日本建築学会研究報告 22 号, 昭和 28 年度春季大会

12）鈴木成文ほか：新・旧住民混在地区の問題 1 4, 日本建 築学会大会学術講演梗概集, 昭和 47 年 10 月

13）総理府国立世論調査所：地方自治世論調査，町内会・部 落会・隣組について, 昭和 27 年 11 月

14）上田 篤：京町家, コミュニティ研究, 鹿島出版会, 昭 和 51 年 6 月

15）戸沼幸市：人口尺度論，居住環境の人間尺度，彰国社, 昭和 55 年 12 月

16）斉木崇人ほか：住環境形成の基礎単位としてみた集落の 環境整備計画に関する研究 2 , 日本建築学会大会学術講 演梗概集, 昭和 55 年 9 月

17）野口美智子：近隣自治組織の単位に関する研究, 日本建 築学会大会学術講演梗概集, 昭和 52 年 10 月

18）斉木崇人ほか：住環境形成の基礎単位としてみた集落の 環境整備計画に関する研究 5 , 日本建築学会大会学術講 演梗概集, 昭和 55 年 9 月

19）小泉正太郎：団地内施設の整備基準に関する研究，日本 住宅公団調查研究期報 No. 59, 昭和 53 年

20）小柳津醇一ほか：集合住宅における近隣関係と生活領域 に関する研究, 住宅建築研究所報, 昭和 57 年

21）高見沢邦郎・川崎和裕：老朽 RCアパートにおける維持 管理更新の問題点, 日本建築学会大会学術講演梗概集, 昭和 48 年 10 月

22）鈴木成文：都市型低層住宅の計画設計手法に関する研究, 日本住宅公団調查研究期報 No. 64, 昭和 55 年 6 月

23）山本俊治・谷村広一：コーポラティブハウジングの実態 調查報告, 日本住宅協会 27 回住宅問題研究発表会梗概集, 昭和 54 年

24）神谷宏治：協空間とコミュニティ, コープ住宅の視点か ら, 日本住宅協会「住宅」, 昭和 58 年 11 月所収 
25）石崎宣雄：青森県における町内会・部落会等の実態, 青 森県新生活協議会県民運動資料センター, 昭和 54 年 5 月

26）〈竹山〉は団地，〈多摩〉は管理組合の住棟群の中の「中 心的な場所』と考えるところを居住者に直接たず好た。

27）〈竹山>は団地,<多摩〉は管理組合の住棟群の中で, 「彫 刻・噴水, タワーなどのシンボル的なものがあったら良 いよ思うところを居住者に直接たずねた。

28）本研究における調查対象の一つであるく多摩・高層〉で は，エレベーター単位の縦の近榉単位に加えて，2 層毎 の自主防災会で横のつながりを図っている。

29）日本住宅公団：諸外国における集団住宅とその管理に関 する研究, 昭和 36 年

30）䦣（イキ，しきみ）は敷居の意味に用いられることもあ るが, 元来は門下の横木のことで, 門限や内外の区切り, 更には, 意識の可能・不可能の境界 (識䦭), 刺激の有効 無効の境界 (刺激闘) 等の意味に用いられる。

\section{参考文献}

(上記文献以外に参考にした文献は以下のとおりである)

1）野口瑠美子：集合住宅団地における近隣意識亡領域の段 階性について，日本住宅協会第 32 回住宅問題研究発表会 梗概集, 昭和 59 年

2）野口瑠美子：集合住宅における近隣空間構成に関する一 考察, 日本住宅協会第 1 回ハウジング研究報告会, 昭和 60 年

3）谷口汎邦・野口瑠美子：集合住宅団地における近隣意識 について, 日本建築学会大会学術講演梗概集, 昭和 57 年 10 月

4）谷口汎邦・野口瑠美子：集合住宅における近隣との接点
空間と近隣意識との関係, 日本建築学会大会学術講演梗 概集, 昭和 58 年 9 月

5）谷口汎邦・野口瑠美子ほか：住戸まわりの共用空間に関 する機能的要求について, 高層高密度集合住槙における 共用空間について，住棟内共用空間事例〈赤い広場〉の 利用之意識, 日本建築学会大会学術講演梗概集, 昭和 52 年 10 月

6）谷口汎邦・野口瑠美子ほか：集合住宅における住戸迴り の路地的スペースについてI・I，日本建築学会大会学 術講演梗概集, 昭和 53 年 9 月

7）谷口汎邦・野口瑠美子ほか：集合住宅における住戸出入 ロまわりの空間構成事例について, 集合住宅における住 戸まわりへの侵出物品状況よりみた住戸内・外の施設 · 空間化について，集合住宅における住戸まわりの共用空 間機能の設置条件について，集合住宅における住戸まわ り計画の条件に関する $2 \cdot 3$ の考察, 集合住宅における住 戸迴りの空間形態と共用空間機能要求について, 日本建 築学会大会学術講演梗概集, 昭和 54 年 9 月

8）谷口汎邦・野口瑠美子ほか：高層集合住棟における住 戸・住棟まわりの生活施設・空間・設備機能に関する居 住者要求意識について, 日本建築学会大会学術講演梗概 集, 昭和 55 年 9 月

9）野口瑠美子：高層集合住宅における共用空間についての 一考察, 東海大学教養学部紀要第 9 輯, 昭和 53 年

10) Weeber + Partner : Gemeinschaftseinrichtungen, Karl Krämer Verlag, Stuttgart, 昭和 50 年

11) Ulfert Herlyn : Wohnen im Hochhaus, Karl Krämer Verlag, Stuttgart, 昭和 45 年

\section{SYNOPSIS}

UDC : 728.2:728.011:72.011.21

\section{THE RELATIONSHIP BETWEEN THE PHYSICAL AND SOCIAL ATTRIBUTES OF NEIGHBORHOOD AND ITS TERRITORIALIZATION IN MULTIPLE DWELLING HOUSE ESTATE}

A study on neighborhood planning, Part 1

by RUMTKO NOGUCHI, Associate Prof. of Tokai Univ. and Dr. HIROKUNI TANIGUCHI, Prof. of Tokyo Institute of Technology, Members of A.I. J.

In this paper, the effects of neighborhood planning on inhabitants are viewed in the light of the daily behavior and feelings of inhabitants, neighborhood cohesion and the social relationships with their neighbors, using survey data in multiple dwelling house estates. In its analysis, the relationships between the perception of territory on the one hand, and the housing type, the number of grouped dwelling units, the way of approach to individual dwelling unit, the human contact with neighbors, the united activities among neighbors and the like on the other are examined. As a result, the neighborhood was classifyed into two or three divisions in terms of the perception of territory, in the case of surveyed housing estates. In addition, It was realized that the physical and social thresholds and nuclear spaces in neighborhood played an important part, whenever inhabitants perceived a certain territory. In other words, the possible interaction effects among the perception of territory, threshold and nuclear space in neighborhood were suggested. 